W stużbie tradycji i odnowy liturgicznej. 50 lat Instytutu Liturgicznego w Krakowie (1968-2018), red. P. Nowakowski, J. Mieczkowski, Kraków 2019, s. 207-220.

ISBN 978-83-7438-849-8 (wersja drukowana), ISBN 978-83-7438-850-4 (wersja online) DOI:http://dx.doi.org/10.15633/9788374388504.17

Bogusław Migut

Katolicki Uniwersytet Lubelski w Lublinie, Polska

ORCID: 0000-0002-8832-5429

\title{
Liturgia jako theologia prima. Kierunki i najważniejsze osiągnięcia badań nad liturgią na Katolickim Uniwersytecie Lubelskim Jana Pawła II
}

Aktualnie badania nad liturgią na KUL prowadzone są w Instytucie Liturgiki i Homiletyki, który w latach 2001-2005 istniał jako Instytut Liturgiczno-Homiletyczny, a wcześniej jako specjalizacja liturgiczna i homiletyczna w ramach Sekcji Teologii Pastoralnej, a następnie Instytutu Teologii Pastoralnej. Instytut pod obecną nazwą (Instytut Liturgiki i Homiletyki) istnieje od roku 2009. Jego pierwszym dyrektorem był ks. prof. dr hab. Władysław Głowa (2001-2005; 2009-2012), a obecnie jest nim ks. dr hab. Bogusław Migut, prof. KUL.

\section{Geneza Instytutu Liturgiki i Homiletyki}

Instytut Liturgiki i Homiletyki prowadzi badania naukowe i zajęcia dydaktyczne z zakresu liturgiki, które zostały zapoczątkowane w 1924 roku, i homiletyki, zapoczątkowane w 1959 roku. Jest on spadkobiercą specjali- 
zacji liturgicznej i homiletycznej, które przynależały do Instytutu Teologii Pastoralnej od 1959 roku. Katedra Teologii Liturgii została utworzona 16 maja 1958 roku w ramach Wydziału Teologicznego KUL i Sekcji Teologii Pastoralnej wraz z trzema innymi katedrami: Teologii Pastoralnej Ogólnej, Socjologii Religii i Psychologii Duszpasterskiej. Następnie po reformie Sekcji Pastoralnej, według zaleceń konstytucji Deus scientiarum Dominus, w 1964 roku utworzono trzy specjalizacje: pedagogiczno-katechetyczna, liturgiczno-homiletyczną i hodegetyczno-socjologiczną. W roku 1968 został utworzony Instytut Teologii Pastoralnej z trzema specjalizacjami: socjologiczno-pastoralną, liturgiczno-homiletyczną i katechetyczno-pedagogiczną. W roku akademickim 1972/1973 w Instytucie Teologii Pastoralnej została utworzona Katedra Liturgiki, której kierownikiem był ks. dr Wacław Schenk (1913-1982). Po jego tragicznej śmierci kuratorem Katedry do 1987 roku był ks. prof. dr hab. Romuald Rak (1920-2003). Następnie uchwałą Rady Wydziału Teologii z 23 maja 1987 roku kierownictwo Katedrą przejął prof. dr hab. Jerzy Józef Kopeć CP (1938-2010). W 1997 roku z Katedry Liturgiki powstały dwie nowe katedry: Katedra Historii Liturgii i Katedra Teologii Liturgii.

W 1970 roku została utworzona Katedra Homiletyki, a jej kuratorem został ks. Stanisław Łach. W 1972 roku obowiązki kuratora Katedry Homiletyki podjął ks. Józef Kudasiewicz. Funkcję tę pełnił aż do 1982 roku. W 1982 roku kierownikiem Katedry Homiletyki zostaje ks. dr hab. Mieczysław Brzozowski. Po jego śmierci w 1991 roku powołano kuratora Katedry, którym ponownie zostaje ks. prof. dr hab. Kudasiewicz. Na stanowisku tym zastępuje go w 1994 roku ks. prof. dr hab. Anzelm Weiss. W 1996 roku powołano kierownika Katedry Homiletyki, którym zostaje ks. prof. dr hab. Władysław Głowa. W 2007 roku w ramach specjalizacji homiletyki utworzono Katedrę Komunikacji Religijnej i powierzono jej kierownictwo ks. dr. hab. Włodzimierzowi Brońskiemu; funkcjonowała ona do jego odejścia na Wydział Prawa KUL w 2011 roku. W 2009 roku z Katedry Homiletyki wydzielono dwie nowe katedry: Katedrę Homiletyki Materialnej, której kierownikiem był ks. dr hab. Stanisław Dyk, oraz Katedrę Homiletyki Fundamentalnej, kierowaną przez ks. prof. dr. hab. Władysława Głowę. W takim układzie katedry te funkcjonowały do 2014 roku, kiedy to na emeryturę odszedł ks. Władysław Głowa. Od tej pory w ramach specjalizacji homiletycznej istnieje jedna katedra - Katedra Homiletyki, której kierownikiem jest ks. prof. dr hab. Stanisław Dyk. Pierwszą próbą 
stworzenia odrębnego instytutu było utworzenie Instytutu Liturgiczno-Homiletycznego w 2001 roku z inicjatywy prof. dr. hab. Jerzego Józefa Kopcia CP. Wykazywał on, że liturgika i homiletyka od 1964 roku były ściśle ze sobą powiązane, ponadto liturgika i homiletyka powinny być uprawiane jako dyscypliny teologiczne niezależne od teologii pastoralnej, dogmatycznej czy biblijnej, ale pozostawać z nimi związane. Instytut ten istniał do 2005 roku, kiedy stał się na nowo częścią Instytutu Teologii Pastoralnej. Właściwe istnienie Instytutu rozpoczyna się w 2009 roku.

\section{Struktura Instytutu Liturgiki i Homiletyki}

Do roku akademickiego 2017/2018 w skład Instytutu wchodziły: Katedra Historii Liturgii, Katedra Homiletyki, Katedra Liturgiki Pastoralnej, Katedra Teologii i Duchowości Liturgicznej oraz Instytut Formacji Pastoralno-Liturgicznej. Od roku 2017/2018 obowiązuje w Instytucie na specjalizacji liturgicznej i homiletycznej skorygowany program studiów doktoranckich. Korekta polegała na zmniejszeniu liczby zajęć oraz prowadzeniu ich w cyklu dwuletnim. Od roku akademickiego 2017/2018 w Instytucie są trzy katedry: Katedra Historii Liturgii, Katedra Teologii Liturgii i Katedra Homiletyki. Kierownikiem Katedry Historii Liturgii jest ks. prof. KUL dr hab. Waldemar Pałęcki, a pracownikami są ks. prof. dr hab. Zdzisław Janiec i prof. KUL dr hab. Michał Wyrostkiewicz. Katedrą Teologii Liturgii kieruje ks. prof. KUL dr hab. Bogusław Migut, a jego współpracownikami są: ks. dr Zbigniew Głowacki, ks. dr Tomasz Lisiecki i ks. dr Andrzej Megger. Katedra Homiletyki kierowana jest przez ks. prof. dr. hab. Stanisława Dyka, a pracownikami Katedry są ks. prof. KUL dr hab. Piotr Kulbacki i ks. dr Michał Klementowicz.

\section{Kierunki badań Instytutu Liturgiki i Homiletyki}

\subsection{Badania nad historią liturgii}

Podejmowane są głównie w Katedrze Historii Liturgii, która swymi korzeniami nawiązuje do powstania w roku akademickim 1959/1960 seminarium historii liturgii pod kierunkiem ks. prof. dr. hab. Mariana Rechowicza 
(zm. 1983) i późniejszej Katedry Liturgiki pod kierownictwem ks. prof. Wacława Schenka (zm. 1982). W 1997 roku dotychczasowa Katedra Liturgiki została podzielona na Katedrę Teologii Liturgii oraz Katedrę Historii Liturgii, której kierownikiem został ks. dr hab. Zbigniew Wit, prof. KUL. Funkcję tę pełnił do momentu przejścia na emeryturę w 2011 roku. Od I stycznia 2013 roku kierownikiem jest dr hab. Waldemar Pałęcki MSF, prof. KUL, a jego współpracownikami są ks. prof. dr hab. Zdzisław Janiec oraz dr hab. Michał Wyrostkiewicz, prof. KUL.

Problematyka badawcza dotyczy przede wszystkim poznania dziejów liturgii w Polsce na podstawie rękopiśmiennych i drukowanych ksiąg liturgicznych. Badania te określono w ścisłym tego słowa znaczeniu jako „lubelską szkołę historii liturgii”. Potwierdzają to publikacje i wystąpienia pracowników z zakresu historii, odnoszące się między innymi do liturgii sakramentu bierzmowania, sakramentów chorych czy śpiewów na ziemiach polskich. Zadania te są kontynuowane w zakresie liturgii potrydenckiej - szczególnie zakonnej - i dotyczą kamedułów polskich i benedyktynów.

Do największych osiągnięć badawczych należą monografie:

- Pałęcki W., Rok liturgiczny Pascha Chrystusa. Misterium roku liturgicznego wedtug Odo Casela (1886-1948), Sandomierz 2006 (Nagroda im. ks. prof. Adama Duraka SDB przyznana 20 października 2006 roku);

- Pałęcki W., Stużba Boża kamedułów polskich. Tradycje życia pustelniczego w świetle potrydenckiej liturgii rzymskiej (1605-1963), Lublin 2012;

- Pałęcki W., Pytanie o liturgię. Misterium liturgii w życiu Kościoła, Lublin 2015;

- Wit Z., Troska liturgiczna o człowieka chorego na podstawie potrydenckich rytuałów polskich (1631-1964), Lublin 1995;

- Wyrostkiewicz M., Internet i (nie)moralność, Lublin 2015.

\subsection{Badania nad homilią}

Badania prowadzone są w Katedrze Homiletyki, która powstała w 1970 roku. Po tym jak jej kuratorami byli ks. Józef Kudasiewicz i ks. Stanisław Łach, jej pierwszym kierownikiem został w 1982 roku ks. dr hab. Mieczysław Brzozowski. Badania prowadzone wówczas w Katedrze Homiletyki oscylowały głównie wokół historii kaznodziejstwa oraz posoborowej teologii homilii. Po śmierci ks. Brzozowskiego ponownie kuratorem 
Katedry Homiletyki zostaje ks. prof. dr hab. Józef Kudasiewicz. Warto dodać, że ks. Józef Kudasiewicz podczas dwukrotnego kuratorstwa nadał badaniom naukowym z homiletyki wyraźny rys biblijno-antropologiczny. Od 1992 do 1994 roku kuratorem homiletyki zostaje ówczesny dziekan Wydziału Teologii, ks. prof. dr hab. Anzelm Weiss. Następnie, gdy w 1994 roku kierownictwo Katedry Homiletyki obejmuje ks. prof. Władysław Głowa, badania naukowe prowadzone w Katedrze zostają rozszerzone na szerokie spektrum zagadnień homiletycznych. Takiemu rozwojowi badań służyło potem powstanie nowych katedr w ramach specjalizacji homiletyki: Katedry Komunikacji Religijnej, której kierownikiem w latach 2007-2011 był ks. dr hab. Włodzimierz Broński, Katedry Homiletyki Fundamentalnej, której kierownikiem w latach 2009-2014 był ks. prof. dr hab. Władysław Głowa, oraz Katedry Homiletyki Materialnej, której kierownikiem w tym samym czasie był ks. dr hab. Stanisław Dyk. Obecnie w ramach specjalizacji homiletycznej istnieje jedna katedra - Katedra Homiletyki.

W Katedrze Homiletyki realizowane są badania związane z kompleksowym zakresem poszukiwań naukowych właściwych homiletyce jako dyscyplinie teologicznej. Podejmowane są zatem badania związane $\mathrm{z}$ homiletyką fundamentalną, materialną, formalną i szczegółową. Chodzi między innymi o następującą problematykę badawczą: teologiczne podstawy przepowiadania; zbawcza natura homilii oraz jej rola w celebracji liturgicznej; historia kaznodziejstwa; źródła i treść współczesnego przepowiadania; teologiczne podstawy posłannictwa kaznodziei; kulturowe i antropologiczne uwarunkowania przepowiadania; funkcje języka w przepowiadaniu; typy, formy i rodzaje przepowiadania; zagadnienia związane z psychologią pracy twórczej, retoryką i teorią komunikacji. Ponieważ homiletyka ma charakter interdyscyplinarny, badania naukowe prowadzone w Katedrze odwołują się także do osiągnięć innych nauk teologicznych (na przykład biblistyki, dogmatyki, liturgiki) oraz humanistycznych (psychologii, pedagogiki, socjologii, filozofii). Chodzi o uprawianie homiletyki w jej kontekście, a przede wszystkim o ukazanie homilii i homiletyki jako współczesnej próby syntezy teologicznej czy też teologii syntezy (por. DFK 16). Ważnym rysem badań prowadzonych w Katedrze są zagadnienia związane $\mathrm{z}$ hermeneutyką biblijno-liturgiczna, $\mathrm{w}$ tym głównie $\mathrm{z}$ interpretacją lekcjonarza mszalnego. Pokaźne miejsce $\mathrm{w}$ badaniach naukowych prowadzonych w Katedrze Homiletyki zajmuje problematyka związana z nową ewangelizacją. W badaniach tych chodzi głównie o poszukiwanie 
sposobów dotarcia z orędziem Chrystusa - Pana, Zbawiciela i Mesjasza do współczesnego człowieka, zwłaszcza zdechrystianizowanego. Nowa sytuacja życiowa Polaków, proces dechrystianizacji i sekularyzacji, zmieniająca się ludzka moralność, mentalność, problemy i potrzeby domagają się nowych sposobów mówienia o Jezusie Chrystusie. Na plan pierwszy wysuwają się tutaj zagadnienia związane z odnową współczesnej ewangelizacji oraz z przepowiadaniem kerygmatycznym rozumianym jako najkrótsza droga do zrodzenia wiary. W związku z tym w najbliższym czasie planowane jest powołanie na Wydziale Teologii KUL centrum badań nad nową ewangelizacją przy współpracy pracowników trzech katedr: Katedry Homiletyki, Katedry Psychologiczno-Pedagogicznej oraz Katedry Teologii i Duchowości Liturgicznej.

Najważniejsze osiągnięcia zawarte są w następujących publikacjach:

- Głowa W., Niedzielna służba Boża w kościołach parafialnych diecezji przemyskiej w pierwszej połowie XVIII wieku w świetle wizytacji biskupich, Przemyśl 1993;

- Głowa W., Liturgia źródłem i miejscem przepowiadania, Przemyśl 1999;

- Broński W., Formacja homiletyczna alumnów w wyższych seminariach duchownych w Polsce. Studium homiletyczne, Lublin 2007;

- Dyk S., Współczesne przepowiadanie homilijne misteriów publicznego życia Jezusa, Lublin 2008;

- Dyk S., Co głosić, aby wierzyli? Studium homiletyczne lekcjonarza mszalnego, Lublin 2013;

- Dyk S., Nowa ewangelizacja - konkretne wezwanie, Gubin 2015;

- Dyk S., Homilia - droga do żywego poznania misterium Chrystusa, Kielce 2016.

\subsection{Badania nad teologią liturgii i duchowością liturgiczną}

Badania prowadzone były początkowo tylko w Katedrze Teologii Liturgii, która została wydzielona w 1997 roku z Katedry Liturgiki, a jej kierownikiem do grudnia 2003 roku był ks. prof. dr hab. Jerzy Kopeć. Od stycznia 2004 roku do września 2014 roku kierował nią ks. prof. dr hab. Czesław Krakowiak. Podobny kierunek badań, choć bardziej skoncentrowany na duchowości chrześcijańskiej i teologii liturgicznej, miała istniejąca w latach 2008-2014 Katedra Duchowości Liturgicznej, której kierownikiem był ks. dr hab. Bogusław Migut, prof. KUL. W roku 2014 obie katedry 
zostały połączone i w ten sposób powstała Katedra Teologii i Duchowości Liturgicznej. Od roku akademickiego 2017/2018 powrócono do pierwotnej nazwy: Katedra Teologii Liturgii.

W tym nurcie prowadzone są badania nad teologią sakramentów świętych w świetle tekstów euchologijnych, biblijnych oraz aktualnego nauczania Magisterium Kościoła. Drugim ważnym kierunkiem badań jest teologia celebracji liturgii po soborze watykańskim II i uczestnictwa w liturgii całego kapłańskiego ludu Bożego, duchownych i świeckich. Ważne miejsce w pracach Katedry zajmują również studia nad teologią roku liturgicznego, liturgii godzin i kultu świętych. Przedmiotem badań teologicznych jest także relacja różnych form pobożności ludowej do liturgii oraz zasady ich odnowy w duchu posoborowej teologii liturgii. Ponadto istnienie Katedry i kierunek badań wyznaczają tendencje rozwojowe we współczesnej teologii. $\mathrm{W}$ ramach nauk teologicznych począwszy od przełomu XIX i XX wieku dokonuje się uniezależnianie poszczególnych dyscyplin. Szczególnego przełomu w ramach badań nad liturgią dokonał Romano Guardini (1885-1968), który bardziej niż inni współcześni badacze nadał liturgice charakteru autonomicznego wobec teologii pastoralnej, ale też wobec dogmatyki, teologii moralnej i prawa kanonicznego.

Szczególnym przedmiotem badań tego nurtu jest teologia liturgiczna. Najgłębszego powiązania teologii, liturgii i życia chrześcijańskiego dokonały szkoła rzymska teologii liturgicznej i amerykańska szkoła teologii liturgicznej. Badania nad tym zagadnieniem wydają się bardzo ważne dla teologicznej nauki o liturgii, ale też teologii jako całości. Innym ważnym kierunkiem badań jest główny nurt Tradycji chrześcijańskiej pod kątem wyraźnie obecnego w nim związku liturgii z duchowością. Liturgia jawi się tu jako źródło i szczyt życia Kościoła i chrześcijanina. Bardzo ważny kierunek badań stanowi też analiza duchowości zakonów, wspólnot doskonałości chrześcijańskiej i ruchów chrześcijańskich pod kątem jej związku z liturgią.

Wyniki badań ukazane są w następujących publikacjach książkowych:

- Eucharystia. Misterium - ofiara - kult, red. J. J. Kopeć, Lublin 1997;

- Głowacki Z. M., Księdza Adama Ludwika Szafrańskiego teologia liturgii, Lublin 2013;

- Jedna wiara, jedna Msza, red. C. Krakowiak, B. Migut, Lublin 2009;

- Kopeć J. J., Bogurodzica w kulturze polskiej XVI wieku, Lublin 1997 (za tę publikację autor otrzymał Nagrodę Ministerstwa Edukacji Narodowej w 1999 roku); 
- Krakowiak C., Katechumenat chrzcielny dorostych w Kościele posoborowym, Lublin 2003;

- Krakowiak C., Sakrament bierzmowania w reformie liturgii II Soboru Watykańskiego, Lublin 2012;

- Krakowiak C., Wiara. Kościót. Liturgia, Lublin 2016;

- Migut B., Teologia liturgiczna szkoły rzymskiej, Lublin 2007;

- Moc Słowa Pańskiego. Adhortacja apostolska „Verbum Domini” w refleksji biblijno-teologicznej, red. B. Migut, A. Piwowar, Lublin 2012;

- Serce Jezusa w misterium Kościoła. 250 lat kultu Serca Pana Jezusa w Polsce, red. W. Pałęcki, Z. Głowacki, Lublin 2016;

- Święty Jakub z Composteli. Na pielgrzymich szlakach Europy, red. B. Migut, Lublin 2010;

- Teologia liturgiczna. W poszukiwaniu syntezy teologii, red. B. Migut, Lublin 2013.

\subsection{Badania z zakresu liturgiki pastoralnej}

Prowadzone były w latach 2007-2017 w Katedrze Liturgiki Pastoralnej pod kierunkiem ks. prof. dr. hab. Zdzisława Jańca. Celem badań liturgiki pastoralnej jest wypracowanie konkretnych działań duszpasterskich, umożliwiających coraz głębsze i świadome przeżywanie liturgii we wspólnocie Kościoła. Z tego względu pierwszy nurt badań skupia się na istocie kultu maryjnego w liturgii Kościoła. Ponieważ temat pobożności maryjnej wzbudza wiele kontrowersji wśród teologów, mariologów i liturgistów, stąd też istnieje pilna potrzeba merytorycznych badań opartych na nauczaniu Kościoła i socjologicznych analizach. Badania prowadzą do oceny aktualnej sytuacji oraz wskazują konkretne rozwiązania duszpastersko-liturgiczne przy uwzględnieniu teologicznych podstaw kultu maryjnego. Drugi kierunek badań naukowych podejmuje problematykę kształtu życia liturgicznego w diecezjach polskich. Przedmiotem analiz jest wymiar historyczno-praktyczny służby Bożej, który ukazuje rozwój liturgii na przestrzeni dziejów w wybranych diecezjach, a także wymiar praktyczny - badający możliwość adaptacji założeń teoretycznych w konkretnych działaniach liturgiczno-duszpasterskich. Obydwa wymiary badań: historyczny i praktyczny stanowią podstawę do wypracowania prawidłowego modelu liturgiczno-pastoralnego wspólnot Kościoła. Trzeci kierunek badawczy podejmuje zagadnienia formacji liturgicznej, biblijnej i muzycznej osób 
bezpośrednio związanych z liturgią. Podstawę badań stanowią dokumenty Kościoła, które nieustannie wskazują na konieczność kształtowania kandydatów do kapłaństwa, kapłanów, świeckich szafarzy Eucharystii i innych.

W ramach badań pastoralnych i formacyjnych należy wskazać na Instytut Formacji Pastoralno-Liturgicznej. Do roku akademickiego 2018/2019 na Wydziale Teologii KUL prowadzone były niestacjonarne studia doktoranckie w ramach Instytutu Formacji Pastoralno-Liturgicznej (IFPL). Dzieło to stanowi owoc działalności pracowników naukowych ówczesnego Instytutu Teologii Pastoralnej KUL - Czcigodnego Sługi Bożego ks. dr. hab. Franciszka Blachnickiego (zm. 1987) oraz zmarłego w opinii świętości ks. dr. Wojciecha Danielskiego (zm. 1985). W roku 2010 dotychczasowe studia licencjackie Senat Akademicki przekształcił w czteroletnie niestacjonarne studia doktoranckie na Wydziale Teologii KUL, zachowując dotychczasową formułę akademicko-formacyjną dla dwu pierwszych lat studiów - do kanonicznego licencjatu. Bezpośrednie kierownictwo naukowo-dydaktyczne sprawuje Instytut Liturgiki i Homiletyki KUL, opiekę formacyjną zaś Ruch Światło-Życie. Dalsze dwa lata studiów są odbywane w ramach wybranej specjalizacji. Dyrektorem IFPL jest każdorazowy dyrektor Instytutu Liturgiki i Homiletyki. Obecnie jest nim ks. dr hab. Bogusław Migut, prof. KUL. Osobą odpowiedzialną za formację jest ks. dr hab. Piotr Kulbacki, prof. KUL.

Soborowa eklezjologia wskazywała na liturgię jako uprzywilejowane miejsce urzeczywistniania się Kościoła i zarazem miejsce formacji chrześcijanina, nie tylko religijnej, ale osobowej i społecznej. Równocześnie rozwój współczesnej myśli personalistycznej implikował ścisłe powiązanie formacji pastoralnej z liturgiczną jako drogą kształcenia duchowieństwa w duchu soborowym.

Dlatego po uzyskaniu aprobaty najwyższych władz Kościoła w Polsce i władz KUL zainicjowano w roku 1973/1974 nowy typ kształcenia. W roku 1984/1985 Studium Formacji Pastoralno-Liturgicznej przyjęło formę dwuletniego cyklu obejmującego rocznie sześć sesji dwuipółdniowych z wykładami akademickimi i odpowiadającym im programem formacyjnym. W 1996 roku została nadana przez Senat Akademicki nazwa Instytut Formacji Pastoralno-Liturgicznej. Przez kilka lat zajęcia dydaktyczne i formacyjne prowadzono także w Rzeszowie i na Słowacji. Coraz częściej absolwenci IFPL podejmowali dalsze studia doktoranckie, wieńcząc je uzyskaniem doktoratu. 
Tematyka zajęć IFPL i badań naukowych podejmowanych przez doktorantów dotyczy przede wszystkim: socjologicznych i teologicznych podstaw urzeczywistniania się Kościoła; ewangelizacji w Kościele współczesnym; mistagogii wspólnoty, celebransów i zespołów służby liturgicznej; formacji grup apostolskich i indywidualnego kierownictwa duchowego. Specyfiką studiów w Instytucie Formacji Pastoralno-Liturgicznej są obok wykładów liczne ćwiczenia praktyczne odnoszące się do pracy w grupach zaangażowanego laikatu - z dziećmi, młodzieżą i rodzinami, a także zajęcia formacyjne i wspólnota liturgii.

Studia w IFPL stały się udziałem ponad pół tysiąca księży w różnym wieku i o różnym stażu posługi kapłańskiej, pracujących jako katecheci, wikariusze i proboszczowie, pracownicy instytucji kościelnych, księża diecezjalni i zakonni, będących z Polski i z krajów sąsiednich. Łączy ich pasja zaangażowania w posługę kapłańską i potrzeba pogłębiania swych kompetencji wobec wyzwań nowej ewangelizacji.

Osiągnięcia badawcze nurtu pastoralnego zawarte są w ważniejszych publikacjach:

- Janiec Z., Komunikacyjny wymiar liturgii, Sandomierz 2006;

- Janiec Z., Wstawiennictwo Maryi. Studium liturgiczno-teologiczne na podstawie wybranych formularzy okresu zwykłego ze "Zbioru Mszy o Najświętszej Maryi Pannie", Sandomierz 2010;

- Janiec Z., Kult Maryi w Polsce na przestrzeni dziejów. Zarys problematyki, Sandomierz 2013;

- Janiec Z., Z Biblia i liturgia ku wierze, Sandomierz 2015;

- Pasjonat miłości Boga i człowieka. Stuga Boży ks. Wincenty Granat, red. Z. Janiec, Sandomierz 2015;

- Kulbacki P., Liturgia w formacji człowieka ku wolności. Studium w świetle myśli i dzieła ks. Franciszka Blachnickiego, Lublin 2013.

\section{Główne zadania Instytutu}

Celem działalności naukowej ILiH jest kształcenie studentów, głównie w ramach studiów doktoranckich, w dwóch specjalizacjach - liturgice i homiletyce. Pierwszorzędnym zadaniem badawczym jest ukazanie znaczenia celebracji liturgicznej, w tym także homilii, dla teologii i życia chrześcijańskiego. Instytut Liturgiki i Homiletyki jest placówką naukowo-dydaktyczną 
o charakterze interdyscyplinarnym. Przygotowuje specjalistów oraz wypracowuje model praktycznej działalności Kościoła w Polsce. Zajmuje się naukową refleksją nad przepowiadaniem słowa Bożego, ewangelizacją oraz dziejami liturgii, duchowością liturgiczna, teologią liturgii i teologią liturgiczną oraz liturgiką pastoralną.

\section{Czasopisma i serie wydawnicze}

Instytut Liturgiki i Homiletyki wydaje dwa czasopisma - „Roczniki Teologiczne”, z. 8 - „Liturgika” i „Roczniki Teologiczne”, z. 12 - „Homiletyka”. W ramach „Roczników Teologicznych” KUL od 1998 roku ukazuje się osobny, ósmy zeszyt „Liturgika”; wydawcą jest TNKUL. Wcześniej artykuły o tematyce liturgicznej i homiletycznej ukazywały się w zeszycie 6 pod tytułem „Teologia Pastoralna”. Czasopismo zostało wydane w roku 2009 jako „Roczniki Liturgiczne”, a następnie w latach 2010-2013 wychodziło pod nazwą „Roczniki Liturgiczno-Homiletyczne”. Od 2014 roku powróciło do pierwotnej nazwy „Roczniki Teologiczne”, z. 8 „Liturgika”. Czasopismo zawiera najnowsze opracowania z różnych dziedzin badań nad liturgią.

W ramach „Roczników Teologicznych” KUL od 2014 roku ukazuje się osobny, dwunasty zeszyt „Homiletyka”; wydawcą jest TNKUL. Czasopismo to stanowi z jednej strony kontynuację i rozszerzenie z. 8. - "Liturgiki”, a z drugiej strony kontynuację wcześniejszych czasopism homiletycznych: „Przeglądu Pastoralno-Homiletycznego", wydawanego w Kielcach w latach 1997-2000, oraz „Przeglądu Homiletycznego”, wydawanego w Kielcach w latach 2001-2013. Początki „Przeglądu Homiletycznego” sięgają lat 19231939. „Roczniki Teologiczne”, z. 12 są jedynym pismem specjalistycznym w Polsce w całości poświęconym homiletyce i ukazującym się we współpracy z głównymi ośrodkami homiletycznymi w Polsce i na świecie. Jest to odpowiedź na zapotrzebowanie polskiego środowiska homiletycznego.

Jedyną serią wydawniczą są Studia Liturgiczne, której poprzedniczką była seria Studia z Dziejów Liturgii w Polsce, zapoczątkowana przez ks. prof. dr. hab. Mariana Rechowicza, rektora KUL, i jego uczniów, księży profesorów: Wacława Schenka, Jerzego Józefa Kopcia, Marka Zahajkiewicza, Wojciecha Danielskiego, Zbigniewa Wita i innych. Pierwsze tomy redagowali ks. prof. Marian Rechowicz i ks. prof. Wacław Schenk. W ramach tej serii wyszły cztery tomy (t. 1, Lublin 1973; t. 2, Lublin 1976; t. 3, Lublin 
1980; t. 4, Lublin 1982). Następnie zostały wydane dwa tomy z serii Studia Liturgiczne, które zachowywały dotychczasową numerację (t. 5, Lublin 1988 i t. 6, Lublin 1990). Ich redaktorem był prof. dr hab. Jerzy Józef Kopeć CP. Publikacje te zawierały głównie prace dyplomowe (doktoraty i niektóre licencjaty) powstałe na seminariach naukowych prowadzonych przez profesorów KUL. W 2011 roku decyzją wydawcy serii, czyli Towarzystwa Naukowego KUL, została ona wznowiona i choć nadano jej nową formułę, to ciągłość numeracji tomów jest zachowana. Nowe publikacje ze Studiów Liturgicznych podejmują tematykę obecną na dorocznych zjazdach Sekcji Wykładowców Liturgiki na Wydziałach Teologicznych i w Wyższych Seminariach Duchownych w Polsce, a ich redaktorami są przewodniczący i sekretarz tejże Sekcji. Do tej pory wydano osiem kolejnych tomów (nr $7-14)$.

\section{Współpraca Instytutu z ośrodkami zagranicznymi}

W ramach specjalizacji liturgicznej podjęto od 2008 roku stałą współpracę ze specjalizacją liturgiczną na Wydziale Teologii Uniwersytetu Notre Dame (USA, Indiana), od 2015 roku z Katedrą Nauki o Liturgii (Lehrstuhl für Liturgiewissenschaft) na Wydziale Teologii w Trewirze oraz z Niemieckim Instytutem Liturgicznym (Deutsches Liturgisches Institut). Podjęto też międzynarodowy projekt badawczy poświęcony koncepcji teologii liturgicznej. Uczestnikami projektu byli: David Fagerberg (Wydział Teologii Uniwersytetu Notre Dame; USA, Indiana), Manlio Sodi (Papieski Uniwersytet Salezjański w Rzymie), Felix Maria Arocena Solano (Uniwersytet Navarra Hiszpania, Pamplona) oraz ks. Bogusław Migut. Owocem współpracy jest książka, która ukazuje się równocześnie w czterech wersjach językowych i w czterech różnych wariantach. Wersja polska: Teologia liturgiczna. W poszukiwaniu syntezy teologii, red. B. Migut, Lublin 2013.

Współpraca specjalizacji homiletycznej z ośrodkami zagranicznymi to przede wszystkim współpraca z Sezione di Facoltá Teologica d'Italia Settentrionale w Padwie oraz z Uniwersytetem w Niemczech (Universität Würzburg - Lehrstuhl für Pastoraltheologie). 


\section{Summary}

The Liturgy as theologia prima. Avenues and most important achievements of research on the liturgy at the John Paul II Catholic University of Lublin

The work and teaching of Lublin theologian Antoni Nojszewski (1844-1921) was an innovation in the approach to liturgy on the threshold of the $19^{\text {th }}$ and $20^{\text {th }}$ centuries Research on the liturgy in the newly established (1918) Catholic University of Lublin was conducted along various avenues, but attention was concentrated chiefly on deepening and renewing participation in the liturgy. Lecturers on liturgy were, among others, Rev. Władysław Korniłowicz (1884-1946) and Rev. Michał Niechaj (1900-1939), responsible for comparative theology and eastern liturgy. A key moment in research on the Roman liturgy was the opening at KUL of the Section on Pastoral Theology, and, within it, the Department of Liturgy, which in 1964 led to the creation of a specialization in liturgy-homiletics (in the academic year 1973/1974 these specializations were divided). In 1968 the Institute on Pastoral Theology was opened, whose composition included the Department on Liturgy and the Department on Homiletics. The establishment (in 1997) of two separate Departments under the liturgy specialization - he Department of History of the Liturgy and the Department of Liturgical Theology - as well as the separation of the Institute on Liturgy and Homiletics from the Institute of Pastoral Theology (2001-2005 and definitively in 2009) were further steps in the development of research on the liturgy at KUL. Issue 8 of the periodical "Roczniki Teologiczne" [Annals of Theology] (since 1998) is dedicated to this specialization, as is the publication series "Studia Liturgiczne" [Liturgical Studies] (14 volumes).

In the Lublin school of research on the liturgy, the historical aspect has the longest tradition, begun by Bishop Marian Rechowicz (1910-1983). Research issues concern most of all knowledge of liturgy history based on manuscripts and printed texts of liturgical books. The research touches on the cult of Polish saints, the liturgy of the sacraments, celebrations of the liturgical year, and liturgical chant in Polish territories, and also liturgical reform in the Church in Poland. Main representatives of this historical research trend are: Rev. Wacław Schenk (1913-1982), Rev. Wojciech Danielski (1935-1985), Rev. Józef Jerzy Kopeć (1938-2010), and Rev. Zbigniew Wit. Currently Rev. Waldemar Pałecki is focusing his research on post-Tridentine liturgy in religious institutes in Poland, particularly of the Camaldolese and the Benedictines. 
A second, theological, research trend, pursued by Rev. Adam Ludwik Szafrański, and also Rev. Schenk and Rev. Danielski, embraces research on the theology of the holy sacraments in the light of euchologic and biblical texts as well as current teaching of the Church Magisterium. A second important theme is the theology of the celebration of the Eucharist after Vatican Council II and of the participation in the liturgy by the entire Priestly People of God, clerical and lay. Principal researchers of this trend include Rev. Czesław Krakowiak, Rev. Zbigniew Głowacki and Rev. Andrzej Megger. A particularly important subject of this research is Roman and American liturgical theology, which unites within itself research on the theology of the mystery of Christ, the liturgical celebration of it, and Christian life. Rev. Bogusław Migut is engaged in this research and also recently Rev. Zbigniew Głowacki and Rev. Andrzej Megger. This research is inseparably linked to liturgical spirituality. It also includes research on the relationship of the liturgy to Christian morality, which is conducted by Michał Wyrostkiewicz.

Another trend is ritual studies and also the cult of Mary in Poland, researched by Rev. Zdzisław Janiec. The topic of pastoral liturgics is currently found chiefly in the research of the Institute of Pastoral-Liturgical Formation and its Director Rev. Piort Kulbacki. As a separate and important research trend, the connection between liturgical and homiletic themes, though integrally incorporated in the life and academic work of the Institute of Liturgy and Homiletics, must be recognized as a separate and important research trend, causing an osmosis of the two specializations and a focus on the one hand on in-depth systematic research on the word of God in relation to liturgy and sacrament, and on the other hand their focus on the new evangelization. Representatives of this research area are Rev. Władysław Głowa, Rev. Stanisław Dyk, Rev. Michał Klementowicz, Rev. Michał Dąbrówka, and Rev. Bogusław Migut. Additionally, research is conducted on liturgical song and music by Rev. Tomasz Lisiecki. 